\title{
Ideological Views of Islam in Relation to Contemporary Human Rights: An Evaluation
}

\author{
Sheikh Mohammad Towhidul Karim* \\ Mohammad Hasan Murad**
}

\begin{abstract}
Islam, being the religion of nature, embodies all the basic ideas of human rights. The principles of human rights were introduced during the advent of Islam in order to ensure peace, justice, tranquility, morality, dignity, quality and values all over the world. The rights recognized by Islam were established not only to protect special race like Muslims, but also to shelter the non-Muslims. This research is mainly based on secondary data and logic. This article is an attempt to outline the contribution of Islam in the field of human rights and endeavors to establish that the principles of human rights are not the sole outcome of the progress of western civilization.
\end{abstract}

\section{Introduction}

The human rights issue is one of the most fundamental issues and one of the most sensitive and controversial ones. It is a very hot and global issue today. During the recent decades, this problem was more political than being either ethical or legal. From north hemisphere to south hemisphere - across the continents and across the countries - the slogans of human rights are heard louder. Islam is a complete code of life bestowed by Almighty Allah for mankind. It covers all aspects of human rights. Islam prescribes some rights for human beings for peaceful enjoyment.

\footnotetext{
* Lecturer, Department of Law, International Islamic University Chittagong.

** Assistant Professor, Department of Law, International Islamic University Chittagong.
} 
Louis Henkin puts it as "HUMAN RIGHTS is the idea of our time." 1 This is the general view of almost all the jurists of the western world on human rights. But this generally followed idea is misnomer. Human rights philosophy and jurisprudence in Islam has been badly misunderstood, not just by non-Muslims, but also by some Muslim societies that have maintained certain cultural practices in the name of Islam that are not in accordance with, and usually in violation of, Islam. This creates a false image of what Islam should be in practice. It is important to understand what human rights should look like according to true Islamic philosophy and jurisprudence.

Ayatollah Murtadha Mutahhari, a leading Muslim scholar, was one of the founding members of the Islamic Republic of Iran in 1979. In his book "Woman and Her Rights", he outlines the popular views of human rights in Islam and the notion of natural rights. He objects to the European and American secular standards of human rights and says "...we, in the name of these very human rights, believe that we have a right to differ. In our view, the only authoritative source is nature itself which may be regarded as a divine book."

In fact, human rights is not an idea which took a positive shape fourteen hundred years before by Islamic law as found in the Holy Quran and the Sunnah. Human rights took an international character by Islam. Islam has guaranteed human rights and fundamental freedoms.

The western jurists who do not have an idea about Islam or who are ideologically opposed to Islam try to overlook the contribution made by Islam towards the development of global concepts of human rights and fundamental freedoms. The Holy Quran and the Sunnah have made in several occasions references to rights of the different sections of the people of a society. These rights are extended to the enjoyment of the non-Muslims in an Islamic State. In other words, Islam has granted a full-fledged Bill of Rights which is to be accepted throughout the world by the Muslims as well as by the non-Muslims. ${ }^{2}$

\section{Islamic Concept of Human Rights}

It is an undeniable fact that the very conception of human rights in Islamic doctrines is different from many conventional western, socialist, and secular concepts of human rights. The main indicator of the success and failure of the western and secular concepts of human rights is material achievement, while spiritual salvation is the prime 
concern of the Islamic concepts of human rights. In material terms, a state or society may be rich; but its humane character may be awfully poor because of its weak moral, ethical, and spiritual foundation. Without some minimum economic emancipation, no society can hope to maintain its desired moral fabric. A rich humane character and strong moral foundation of a society can be regarded as the goal of Islamic human rights, while material advancement is the means to achieve that goal. ${ }^{3}$

Human Rights in Islam is a divine concept. Unlike the Western and contemporary concept of human rights, human rights in Islam was not the result of any development in human thought. This is why it was the divine arrangement that was a Messenger of Allah with divine guidance. And this divine guidance was completed with the revelation of the Quran. The source of human rights in Islam is the Holy Quran and Sunnah and it is guaranteed by the Holy Quran which is the Constitution of the Muslim Ummah. ${ }^{4}$ Besides the primary source of human rights that is the Holy Quran and Sunnah, the secondary sources are the Constitution or Charter of Madina, historic judgments of Prophet (SAW), and practices of rightly guided caliphs, Ijma and Qiyas. In fact, Islam promoted the universality of the human experience over 1300 years before the United Nations declared it to exist. In this regards Professor Briffault rightly remarks,

"The ideals of freedom for all human beings, of human brotherhood, of the equality of all men before the law, of democratic government by consultation and universal suffrage, the ideals that inspired the French Revolution and the Declaration of Rights that guided the framing of the American Constitution and inflamed the struggle for independence in the Latin American countries were not inventions of the West. They find their ultimate inspiration and source in the Holy Quran. They are the quintessence of what the intelligentsia of Mediaeval Europe acquired from Islam over a period of centuries through the various channels of Muslim in Spain, Sicily, the crusaders and of the ideals propagated by the various societies that developed in Europe in the wake of the Crusades intimidation of the brotherhood association of Islam.", 
One of the basic traits of human rights in Islam is that these rights have been granted by Allah (SWT), and unlike traditional human rights systems no individual or legislative assembly has the right to amend, change, or withdraw them. Every Muslim or administrator who claims to be Muslim must accept, recognize and enforce these rights. All those temporal authorities who claim to be Muslims yet violate the rights sanctioned by Allah are either disbelievers or wrong-doers. When we speak of human rights in Islam we really mean that these rights have been granted by Allah (SWT). ${ }^{6}$

If they fail to enforce or denying the rights that have been guaranteed by Allah (SWT); the verdict of the Holy Qur'an is clear and unequivocal:

"Those who do not judge by what Allah (SWT) has sent down are the disbelievers. They are the wrong-doers (zalimun).They are the evillivers (fasiqun)." 7

Eventually, we would like to say human rights have been conferred upon mankind by Allah (SWT) as His bounty; these are inherent, inalienable, permanent, sacrosanct and inviolable. In a truly Islamic state, these rights would be enjoyed by all its citizens and cannot be violated by the State or by any individual.

\section{The Charter of Madina and Human Rights}

The Charter or Constitution of Madina is a written covenant between Islamic state of Madina and its citizens, particularly non-Muslim. The Prophet (SAW) promulgated it, in 622 A.D., on his capacity as the head of the state soon after his arrival at Madina. Muhammad Hamidullah considered it as the first written constitution of the World. ${ }^{8}$ The sole objectives of the promulgation were to guarantee the rights, duties and obligations of state and citizens towards each other. As Forrest G.A. wrote," "The Messenger of Allah (SWT) began to practice human rights when, as early as 622, he promulgated the Charter of Constitution of Madina". ${ }^{10}$ In fact it was the first written 'Magna Carta' of the World after the Quran and Sunnah of the Prophet (SAW).

\section{The Badar Battle and Human Rights}

In the first hijrah in 623 seventy pagan defeated soldiers of the battle of Badar fell in the hands of the Prophet (SAW), among them were almost all of their ring leaders. They deserved capital punishment with death even under customary law existed during those days. But beyond 
expectation the Prophet (SAW) released them with a minimum as well as honorable amount of ransom for which the Prophet (SAW) could put 'Islam' as a condition of their release. According to Tabari, ${ }^{11}$

"The prisoners of war of Badar were given the best food to eat in a condition when the captors (the Muslims) themselves were taking only plain dates". ${ }^{12}$

They were those people who, for last 14 years, had been the cruelest, unjust and who did not leave any stone unthrown against Muslims. One of them said,

"Blessings be on the people of Madina, because they rode us ride, while they themselves walked, they gave us wheat bread to eat when there was little of it, contenting themselves with dates". ${ }^{13}$

\section{Contribution of Islam to the Development of Modern Concept of Human Rights}

Every man whether he is a believer or unbeliever, he has some basic human rights simply because he is a human being. The important element of human rights in relation to Islam is discussed as under.

\subsection{The Right to Life and Property}

The most basic human rights in Islam is the right to life. The Holy Quran declares it in unambiguous terms:

"Whosoever kills a human being without (any reason like) man slaughter, or corruption on earth, it is as though he had killed all mankind ......"14

If anybody violates such rights, he will be punished on the earth in accordance with Islamic law and also punished in the hereafter. The Holy Quran lays down in the regards -

"And whoever kills a believer intentionally, his recompense is Hell to abide therein, and the Wrath and the Curse of Allah are upon him, and a great punishment is prepared for him". ${ }^{15}$

In the address which the Prophet delivered on the occasion of the Farewell Hajj, he said: 
"Your lives and properties are forbidden to one another till you meet your Lord on the Day of Resurrection." 16

Besides, Islam has conferred the right of property. It has encouraged and motivated people to earn, so that wealth may be generated. Property according to Islam has been created by Allah (SWT) for the benefit of all and not for just a few people. The Quran lays down that -

"All that lies between the heaven and earth belongs to Allah.","

It means that $\mathrm{He}$ is the absolute owner of all things. He has allowed men and women to own property only as a trust. As a trustee, men or women can't hold property by any illegal means.

The Law of Allah (SWT) categorically declares:

"Do not devour one another's wealth by false and illegal means." 18

After the conquest of Egypt, Omar (RA), the second Caliph of Islam, preserved intact the property dedicated to the Christian churches and allowed to continue the grants made by the former government for the support of the priests. ${ }^{19}$

Ali (RA), the forth Chliph of Islam, said:

"The blood and property of the Zimmis are like our blood and property." 20

It is quite evident that Islam has collated right to life with property because right to life is often violated due to disputes relating to property.

\subsection{The Right to Justice}

Justice is the greatest moral virtue. The concept of justice and human rights is closely connected. The Qur'an puts great emphasis on the right to seek justice and the duty to do justice. In the context of justice, the Qur'an uses two concepts: "adl" and "ihsan". Both are enjoined and both are related to the idea of "balance", but they are not identical in meaning. "Adl" is defined by A.A.A. Fyzee as "to be equal, neither more nor less." Explaining this concept, Fyzee wrote:

"...in a Court of Justice the claims of the two parties must be considered evenly, without undue stress being laid upon one side or the other. Justice introduces the 
balance in the form of scales that are evenly balanced." 21

While constantly enjoining " $a d l$ ", the Qur'an goes beyond this concept to "ihsan", which literally means, "restoring the balance by making up a loss or deficiency." 22 In order to understand this concept, it is necessary to understand the nature of the ideal society or community envisaged by the Qur'an.

Stressing this point the Quran says:

"O you who believe! Stand out firmly for justice, as witnesses to Allah, even though it be against yourselves, or your parents, or your kin, be he rich or poor ......."

".......Al Quran declares and I am commanded to be just among 5.3 Equality of Human Beings

Equality means a condition of being equal in degree and value. Equality before law is one of the corner stones of the Islamic Constitution. It is not merely a popular slogan like west. All human beings are equal and belong to one universal brotherhood. It announces that all human being in the world have sprung from the parents (Adam and Eve). ${ }^{25}$ Therefore, they are called brothers-sisters and are equal in their status as human beings. A.A.A. Fyzee said in his book "Outlines of Muhammadan Law" regarding brotherhood:

"From the practical point of view, the principle of brotherhood which Islam has preached and not only preached but made real is one of its greatest glories. Almost all religions have taught brotherhood in different ways, but no religion in history can boast of having made brotherhood so real and actual in everyday life." 26

As far as the Muslims are concerned, there are clear instructions in the Holy Quran and Hadith that in their rights and obligations they are all equals. The prophet (SAW) said that

"The life and blood of Muslims are equally precious." 27 
"The protection given by all Muslims is equal. Even an ordinary man of them can grant protection to any man." 28

As regards equality of mankind just three months before his death, during the farewell of final hajj, he said -

"O people! No Arab has any superiority over a nonArab, nor does a non-Arab have any superiority over an Arab. Nor does a white man have any superiority over a black man or the black man any superiority over the white man. ......." ${ }^{29}$

"The people are all equal like teeth of a comb." ${ }^{30}$

\subsection{The Right to Basic Necessities of Life}

Islam has recognized the right of the needy people that help and assistance will be provided to them. For this reason Zakah was prescribed as one of the basic tenants of Islam. If a Muslim denies the payment of Zakah he/she will be declared as a disbeliever.

The Holy Quran acknowledges and recognizes the right to the basic necessities of life.

"And in their wealth there is acknowledged right for the needy and destitute". ${ }^{31}$

"And they give food, ........to Miskin (poor), the orphan, and the captive". 32

"And in their wealth there is a known right for the beggar and for the destitute." 33

Islam recognizes the right of every person, irrespective of caste, creed and religion, to meet their basic necessities like food, shelter, clothes, education etc.

\subsection{The Right to Education}

Islam imposes much importance on acquiring of knowledge or learning education. The first verses of the Quran revealed to the Prophet (SAW) instructed him to read:

"Proclaim! (or read) in the name of your Lord and Cherisher, Who created. Create man, out of (mere) clot of blood. Proclaim! And your Lord is most 
Bountiful. Who taught (the use of the) pen. Taught man that which he knew not."34

In the first verses of revelation, the Prophet (SAW) was instructed to read. Later on the importance of the pen is described. Pen which is the means to protect human civilization and culture. ${ }^{35}$ Quran is a book which is the source of all knowledge, history, geography and different sciences and it asks mankind to think and increase its knowledge.

The Quran states, “O my Lord, increase my knowledge.” 36

The Qur'an emphasizes the importance of the pursuit of learning even at the time, and in the midst, of war. ${ }^{37}$

Education in the Islamic society is not a mere right for its individuals. It is rather a required duty from every capable person. This concept is based on the Hadith of Allah's Messenger (SAW):

"Seeking knowledge is an obligatory on every Muslim (male and female).", 38

"Knowledge is our friend in the desert, our society in solitude, our companion when bereft of friends." 39

"He who travels to seek any (beneficial) knowledge is considered as a person who is struggling in Jihad for the cause of Allah until he returns (home)." 40

Islam emphasizes the need of the establishment of educational institutions which will produce scholars. Before the advent of Islam, there were not many literate people in the Arabian Peninsula and it may be said that the first written book in Arabic was the Holy Quran. So Islam is the pioneer in introducing right to education and ensuring it for the people.

\subsection{Right to Democracy}

Islam recognizes the democratic rights of the citizens. Right to voting for election of representation, right to criticize the government has been recognized in an Islamic State. Thus, the existence of the opposition party is acknowledged in Islam. They have the right to organize political meeting and gathering. ${ }^{41}$ 
Every man is entitled to the freedom of his thinking and religious beliefs. The Holy Quran said, "There is no compulsion in religion." 42 Freedom of speech is recognized in Islam. But it does not recognize any excess or harsh speech. In the Quran it is said, "Allah loveth not the utterance of harsh speech save by one who hath been wronged." 43 Thus Islam, subject to limitation, recognizes freedom of expression and freedom of the press.

Islam recognizes the right to protest against tyranny of every person, irrespective of caste, creed and religion. Referring to it the Quran says:

"Allah does not love evil talk in public unless it is by someone who has been injured thereby." 44

This means that Allah strongly disapproves of abusive language or strong words of condemnation.

\subsection{Protection from Arbitrary Imprisonment}

Islam has legislated that nobody may be imprisoned unless his guilt has been proved after fair trial in an open court. To arrest somebody just on suspicion and to imprison him without proper court proceeding and without giving him a reasonable opportunity to defend himself is not permissible in Islam. Generally preventive detention is unlawful. In Muwatta of Imam Malik is written, "In Islam no man may be imprisoned without justice."

The Holy Quran says clearly:

"No bearer of burdens shall be made to bear the burden of another.",45 Islam believes in personal responsibility.

\subsection{Right to Privacy}

The Quran says:

"Do not spy on one another." 46

"Do not enter any houses except your own homes unless you are sure of their occupants' consent." 47

The Quranic word "Tajassus" has a wide range of meaning and covers a whole spectrum of activities including bugging, interception and censoring personal mails, eavesdropping, tapping personal telephone calls, investigating a person's financial, family and other confidential affairs. 


\subsection{Enforcement of the Rights}

Islam not only guarantees to ensure human rights but at the same time provides procedures for the enforcement of these rights. The enforcement procedures are dual in nature: one will be conducted by the State machinery, the Court; and another will be conducted in the next world. If any right is infringed by any party the aggrieved person has the right to petition before the Court for the enforcement. ${ }^{48}$ It is evident that Islam recognizes human rights and fundamental freedoms. So the Bosworth Smith rightly remarks in his Mohammed and Mohamadanism:

"It recognized individual and public liberty, secured the person and property of the subjects, and fostered the growth of all civic virtues. It communicated all the privileges of the conquering class to those of the conquered who conformed to its religion, and all the protection of citizenship to those who did not...." 49

\subsection{Individual's Right to Freedom}

Islam has evidently forbidden the primitive practice of capturing a free man, to make him a slave or to sell him into slavery. Islam created a revolutionary change in the status and position of slaves. The Prophet (SAW) says:

"There are three categories of people against whom I shall myself be a plaintiff on the Day of Judgment. Of these three, one is he who enslaves a free man, then sells him and eats this money." 50

At present, the west always raises their voice against slave and slavery. But their voice is not properly implemented yet. As for example, America imports labour and intellect till now from Africa as well as from the undeveloped and developing countries. For this reason, Claude M. Lightfood rightly remarks in case of declaring the characteristic of "Declaration of Independence" (4 July 1776) "Black remained slaves until about 80 years later, women did not receive the right to vote until 112 years later and the working class did not get the legal right to organize and collectively bargain until 150 years later." ${ }^{51}$ But Islam never ever wanted to build slavery. 
IIUC Studies, Vol. 8

\subsection{The Rights of the Combatants and Non-Combatants}

Combatant means a person or group involved in fighting in a war or battle. In the early $7^{\text {th }}$ century, the first Caliph, Abu Bakar (RA), whilst instructing his Muslim army, laid down the following rules concerning warfare:

"Stop, O people, that I may give you ten rules for your guidance in the battlefield. Do not commit treachery or deviate from the right path. You must not mutilate dead bodies. Neither kills a child, nor a woman, nor an aged man. Bring no harm to the trees, nor burn them with fire, especially those which are fruitful. Slay not any of the enemy's flock, save for your food. You are likely to pass by people who have devoted their lives to monastic services; leave them alone."

This instruction was subsequently practiced by Muslim armies during the Crusades.

The instructions of the Prophet (SAW) are as follows:

"Do not kill any old person, any child or any woman." 52

"Do not kill the monks in monasteries" or "Do not kill the people who are sitting in places of worship." 53

\subsection{The Rights of a Ruler towards the Public}

This right is simply based on the contents of the verse of the Glorious Qur'ân:

"Oh you who believe! Obey Allah, and obey the Messenger, and those charged with authority among you." 54

In this regards Prophet (SAW) says:

"Listen and obey, even if a slave man from Ethiopia has been appointed [as a ruler] ......." 55

\subsection{Rights towards Neighbors and Friends}

The rights towards neighbors and friends are conferred by Holy Quran and Sunnah. Allah (SWT) ordained in the Glorious Quran: 
"Worship Allah, and join not any partners with Him; and do good to parents, kinsfolk, orphans, those in need, neighbors ......." 56

Friends do enjoy certain rights according to Islam. This is based on the guiding directions of Prophet (SAW):

"The best of friend and the best of neighbors is the best to them." 57

\subsection{Rights of the Laborers and Employers}

Islam has defined a set of rules and regulations on labor, the labor force and employers as well. An employer, according to Islamic teachings, must establish kind relationships with his employees and labor workforce. This is based on the Hadith of Prophet (SAW) says:

"I am the adversary of three [types of] people on the Day of Judgment. ... and a man who employs a worker but does not pay him his [full] wages." 58

"The Almighty Allah likes a worker to be perfect in his work.",59

Moreover, Islam requires an employer to declare the wages to the worker before the worker embarks on the required work. ${ }^{60}$

Islam has given high regard for work. Those who work and earn their living by their own labor must be respected. Of course, the work has to be lawful and it should be done in an honest and sincere manner. All anti-social works, irresponsible behavior, and work done with cheating and deception are forbidden in Islam. Employers and employees all must be honest and must deal with each other justly. All Islamic provisions relating to labor and work go hand in hand with international labor rights instruments for example different ILO Conventions. $^{61}$

\section{The Adaptation of Modern Human Rights in Islam}

Islam and modern concept of human rights share the same objective the human welfare, prosperity and happiness; but while the modern human rights is concerned to secure them at material level through physical means and during this life only, Islam being a religion, is concerned to secure them in all levels, through every available means both here and hereafter. Islam recognizes the inter-play and interaction of all values and neglects none, but pays due regard to the need of coordination between them. A certain primacy must be assigned to 
and observed in respect of moral and spiritual values. Moral primacy is not the primary concern of the modern human rights. This divergence of approach leaves open the possibility of conflicting provisions for the regulation of a specific detail. If this kind of conflict surface then established Islamic provisions should have priority to be enforced in an Islamic society because the goal is to establish peace and harmony rather than following the human rights legislation strictly. However, we must employ our utmost effort to find common grounds to resolve the conflict as far as possible.

Subject to the contingency as outlined above, the revival and strengthening of true Islamic values would only help and further the achievements of the objective of human rights.

Around the world there is a new kind of revolution in Muslim thoughts. We are experiencing a healthy revival of Islam in all respects in this century. The most significant and hopeful feature of this revival is that the attention is being more and more directed to the Quran in the search of light and guidance in the fast growing complexity of the condition and values with which man is confronted today. Surely Islam has the potential to deliver the most effective realization of human rights among the people.

\section{Conclusion}

Unlike many modern systems of human rights, Islam recognizes human rights as a one of the core concepts of social justice and provides strong enforcement measures to ensure peace and prosperity of the human race. The Almighty Allah knows best what benefits man, what harms man, what makes man happy, what makes man successful, what makes man miserable and so on. He is the Best Knower. He knows what suits best and fulfills the entire needs of His creatures on earth and makes their lives successful, secure and joyful. On the other hands, western civilization is morally bankrupt today, and a bankrupt civilization has nothing much to offer. Muslims were supposed to be the guardians and protectors of human right but most unfortunately they failed to unite as a strong ummah resulting in the domination of the western world. We strongly feel that the time has come to claim the guardianship of human rights introduced by Islam and to end the sufferings of mankind by following the true spirit of Islam. 


\section{References}

1 Henkin, Louis (ed.), The International Bill of Rights Vol.1 (New York: Columbia University Press, 1981)

2 Patwari, A.B.M. Mafuzul Islam, Human Right in Islamic Law and Modern International Law: A Comparative Study, p. 258.

3 Khan, Maimul Ahsan, "Human Rights in the Muslim World”, Carolina Academic Press, North Carolina, p. 240.

4 For details see Abdur Razzaq, 'Human Rights in Islam: Issues of Iraq, Afghanistan \& Palestine', Souvenir published by International Islamic University Chittagong and World Assembly of Muslim Youth, (2004), p. 44.

5 Bari, M. E., Human Rights in Islam with Special Reference to Woman's Right, paper presented at the International Seminar on Human Rights in Islam, 5th Oct. 1994, p.18.

6 Mawdudi, Abu al-'A'la, “Human Rights in Islam”, Al Tawhid Journal, Vol. IV, No. 3 Rajab-Ramadhan 1407.

7 Suran Al Anam, 5: 44-45, 47.

8 Hamidullah, Muhammad, The First Constitution of the World, Sh. Muhammad Ashraf Ltd, ed. 1st, 1981, Lahore, Pakistan.

9 Forrest, G.A., “Constitution and Constitutional Law," reported in Encyclopaedia Britannica, p.398.

10 The Document was written as Kitab. For example it began with "Hadha Kitabun min Muhammad - that is the Kitab from Muhammad (SAW). See the First Written Constitution of the World, Muhammad Hamidullah, op.cit., p.54.

11 Tabari, Abu Jafar Ibn jarir, Tarikh al Rusul wa al Muluk, Dar al Maarif, ed. reprint, Qahirah, 1977, vol. 11, pp. 460-61/1338. See also Shibli Numani, Siratun Nabi, Adarah-I-Adabiyat-I-Delhi, Jayyed Press, ed. reprint, Delhi, India, 1983, vol. 11, p, 25.

12 Ibid. The ransom taken from a POW varied form 1,000 to 4,000 Dirham each. Those were unable to pay it they were unable to pay it they were also finally set free at an honourable agreement. Such as, to teach some of the unlettered captors for a particular period of time. What a nice condition is! Die-hard enemy captives turned into honorable teachers! 
However, who was neither in a position to teach nor to pay the ransom, they were also finally set free unconditionally.

13 Ibn Hisham, Muhammad Abdul Malik, Siratun Nabi, Dar al Hidayah, Qahirah, n.d., vol. 1l, p. 288.

14 Surah Al Maida, 5:32.

15 Surah An Nisa, 4:93.

16 Al Bukhari and Muslim.

17 Surah Al-Hashr,59:1

18 Surah Bacara, 2:288.

19 Makrizi, pp. 492, 499.

20 Ali, Amir, "The spirit of Islam", (translated by Mashud Hasan), Ghanokosh Prokashani, Dhaka (2006), p.65.

21 Fyzee, Asraf. A.A., A Modern Approach to Islam, p. 17 (Lahore: Universal Books, 1978).

22 Parwez, G.A., Tabweeb-ul-Qur'an, (Urdu), Volume I, p. 78 (Lahore: Idara-e-Tulu'-e-Islam, 1977).

23 Surah An Nisa, 4:135.

24 Surah As Sura, 42:15.

25 Surah Al Huzurat, 49:13.

26 Fyzee, Asaf A.A., Outlines of Muhammadan Law, Third Edition, Oxford University Press, London, p. 13 (INTRODUCTION).

27 Abu Dawud and Ibn Majjah.

28 Al-Bukhari, Muslim and Abu Dawud.

29 Ibn Hisham, Siratun Nabi, op.cit., 276.

30 Al Nasu Sawasiatun ka Asnan al Misht, Nasai, Sunan, (k) al Qasamah.

31 Surah Zariat, 51:19.

32 Surah Addahor, 76:8.

33 Surah Al Maazez, 70:24-25. 
34 Surah Al-Alaq, 96:1-5.

35 Hameedullah, Mohammed, Khutbat-e-Bahawalpur 7th Edition (Islamabad: Idara Tehqeeqat-e-Islami, Reprint: 2001), p.261.

36 Surah Toaha, 20:114.

37 Reference here is to Surah At-Tawbah, 9:122.

38 Ibn Majah, Hadith No. 337.

39 Ali, Ameer, The Sprit of Islam, (translated by Mashud Hasan), Ghanokosh Prokashani, Dhaka (2006), p.360.

40 Tirmithee, Hadith No. 2785.

41 Patwari, A.B.M. Mafuzul Islam, Human Right in Islamic Law and Modern International Law: A Comparative Study, p. 262.

42 Surah Bacara, 2:256.

43 Surah An Nisa, 4:148.

44 Surah An Nisa, 4:148.

45 Surah Al Anam, 6:164.

46 Surah Al Huzurat, 49:12.

47 Surah An Noor, 24:27.

48 Patwari, A.B.M. Mafuzul Islam, Human Right in Islamic Law and Modern International Law: A Comparative Study, p. 264.

49 Galwash, Ahmad A., The Religion of Islam (Cairo: Al-Ettemad Press, 1945) p.89.

50 Al-Bukhari and Ibn Majjah.

51 Laghtfood, Claude M., Human Rights U.S. Style from Colonical Times through the New Deal, International Publishers, New York, 1977, p.16.

52 Abu Dawud.

53 Musnad of Ibn Hanbal.

54 Surah An Nisa, 4:59.

55 Muslim, Hadith No. 1838. 
IIUC Studies, Vol. 8

56 Surah An Nisa, 4:36.

57 Tirmithee Hadith No. 2009.

58 Bukahri, Hadith No. 2114.

59 Abu Ya'la Hadith no. 4386 and Baihaqi in al-shuab Hadith no. 5312.

60 Baihaqi and Abdul Razzaq in al-Mosannaf.

61 There are as many as 189 conventions till 2011. 